Short communication

\title{
First record of elasmobranchs from the Lower Cretaceous of Argentina (Neuquén Basin)
}

\author{
Soledad Gouiric-Cavalli ${ }^{\text {a, b, * }}$, Alberto L. Cione ${ }^{\text {a, b }}$, Darío G. Lazo b, c, Cecilia S. Cataldo ${ }^{\text {b, c }}$, \\ María B. Aguirre-Urreta b, c \\ a División Paleontología Vertebrados, Museo de La Plata, Paseo del Bosque S/N, B1900FWA, La Plata, Buenos Aires, Argentina \\ ${ }^{\mathrm{b}}$ Consejo Nacional de Investigaciones Científicas y Técnicas, Argentina \\ c Instituto de Estudios Andinos “Don Pablo Groeber”, Departamento de Ciencias Geológicas, Facultad de Ciencias Exactas y Naturales, Universidad de Buenos \\ Aires, Pabellón II, Ciudad Universitaria, C1428EGA, Ciudad Autónoma de Buenos Aires, Argentina
}

\section{A R T I C L E I N F O}

\section{Article history:}

Received 25 December 2016

Received in revised form

19 August 2017

Accepted in revised form 5 September 2017

Available online 13 September 2017

\section{Keywords:}

Chondrichthyes

Agrio Formation

South America

Gondwana

\begin{abstract}
A B S T R A C T
The material reported herein comes from the Lower Cretaceous Agrio Formation (Neuquén Basin, westcentral Argentina). These fishes dwelled in a Pacific Ocean embayment in southwestern Gondwana before the establishment of the Andean Cordillera. The material consists of an incomplete dorsal fin spine of the widespread Hybodontoidea clade (from upper Valanginian beds) and a partial tooth of one of the earliest known lamniforms (from upper Hauterivian beds).
\end{abstract}

๑) 2017 Elsevier Ltd. All rights reserved.

\section{Introduction}

In southwestern Gondwana (South America and Antarctica) chondrichthyans are frequently reported from Upper Cretaceous and Cenozoic beds but Jurassic and Lower Cretaceous records are extremely rare (Arratia and Cione, 1996; see Table 1). Moreover, elasmobranchs from pre-Aptian (early Cretaceous) times are scarcely known worldwide (Guinot and Cavin, 2015).

In this paper, we present a fragmentary hybodont fin spine and a lamniform shark tooth collected at two different stratigraphic levels of the Agrio Formation in the Neuquén Basin and assess the relevance of these new records.

\section{Material and methods}

The studied specimens here were by-catch recovered while performing a stratigraphic log and sampling of invertebrates of the Agrio Formation at Pichaihue section (Fig. 1). After twenty-five

\footnotetext{
* Corresponding author. División Paleontología Vertebrados, Museo de La Plata, Paseo del Bosque S/N, B1900FWA, La Plata, Buenos Aires, Argentina.

E-mail address: sgouiric@fcnym.unlp.edu.ar (S. Gouiric-Cavalli).
}

years of exploration and exploitation of the section, these are the first chondrichthyan remains found in this formation.

\subsection{Institutional abbreviations}

MOZ, Museo Provincial Prof. Dr. Juan A. Olsacher, Zapala, Neuquén, Argentina; MLP, Museo de La Plata, La Plata, Buenos Aires, Argentina.

\subsection{Material preparation techniques}

The specimens were mechanically prepared using pneumatic tools, needles, and widia tool tips. The study was done under a binocular microscope with different magnifications. Photographs were taken with digital cameras. Measurements were taken with digital Vernier caliper directly on the material as well as with the Fiji free software using high-resolution photographs.

\subsection{Descriptive terminology}

Anatomical description terminology follows Patterson (1966), Maisey (1978), and Cappetta (2012); the one for the histology follows Maisey (1978). 
Table 1

Southwestern Gondwana (South America and Antarctica) Late Jurassic-Early Cretaceous elasmobranch records.

\begin{tabular}{|c|c|c|c|}
\hline Taxa & Unit/Locality & Age & References \\
\hline \multicolumn{4}{|l|}{ Batomorphii } \\
\hline $\begin{array}{l}\text { 'Rhinobatidae' indet. } \\
\text { Batomorphii }\end{array}$ & Vaca Muerta Formation, Argentina & Late Jurassic & Cione (1999); Cione et al. (2002). \\
\hline Stahlraja sertanensis & Santana Formation, Brazil & Early Cretaceous & Brito et al. (2013) \\
\hline $\begin{array}{l}\text { Heterodontiformes } \\
\text { Hexanchiformes }\end{array}$ & Apleleg Formation, Chile & Early Cretaceous & Bell and Suárez (1997); Suárez (2015) \\
\hline $\begin{array}{l}\text { Hexanchidae indet. } \\
\text { Hybodontiformes }\end{array}$ & Kotick Point Formation, Antarctica & Early Cretaceous & Cione and Medina (2009) \\
\hline $\begin{array}{l}\text { Priohybodus arambourgi } \\
\text { Hybodontiformes }\end{array}$ & Tacuarembó Formation, Uruguay & Late Jurassic Kimmeridgian-?earliest Cretaceous & Perea et al. (2001); Soto et al. (2012) \\
\hline Lissodus nitidus & Ilhas Formation, Brazil & Early Cretaceous & Brito and Richter (2015) \\
\hline $\begin{array}{l}\text { Hybodontiformes } \\
\text { Hybodontiformes }\end{array}$ & Missão Velha Formation, Brazil & earliest Cretaceous/pre-Aptian & Cupello et al. (2012) \\
\hline $\begin{array}{l}\text { Tribodus limae } \\
\text { Hybodontiformes }\end{array}$ & Santana Formation, Brazil & Early Cretaceous & Brito and Ferreira (1989) \\
\hline $\begin{array}{l}\text { Acrodus nitidus } \\
\text { Hybodontiformes }\end{array}$ & Marfim Formation, Brazil & Early Cretaceous & Woodward (1888); Lindoso et al. (2016) \\
\hline $\begin{array}{l}\text { Planohybodus marki } \\
\text { Hybodontiformes }\end{array}$ & Malhada Vermelha Formation, Brazil & Early Cretaceous & Pinheiro et al. (2011) \\
\hline $\begin{array}{l}\text { gen. et sp. indet. } \\
\text { Synechodontiformes }\end{array}$ & Rosablanca Formation, Colombia & earliest Cretaceous & Carrillo-Briceño et al. (2016) \\
\hline Palaeospinascidae indet. & Lo Valdés Formation, Chile & Late Jurassic & Suárez and Otero (2011); Suárez (2015) \\
\hline Palaeospinascidae indet. & Spartan Glacier Formation, Antarctica & Early Cretaceous & Kriwet (2003) \\
\hline
\end{tabular}

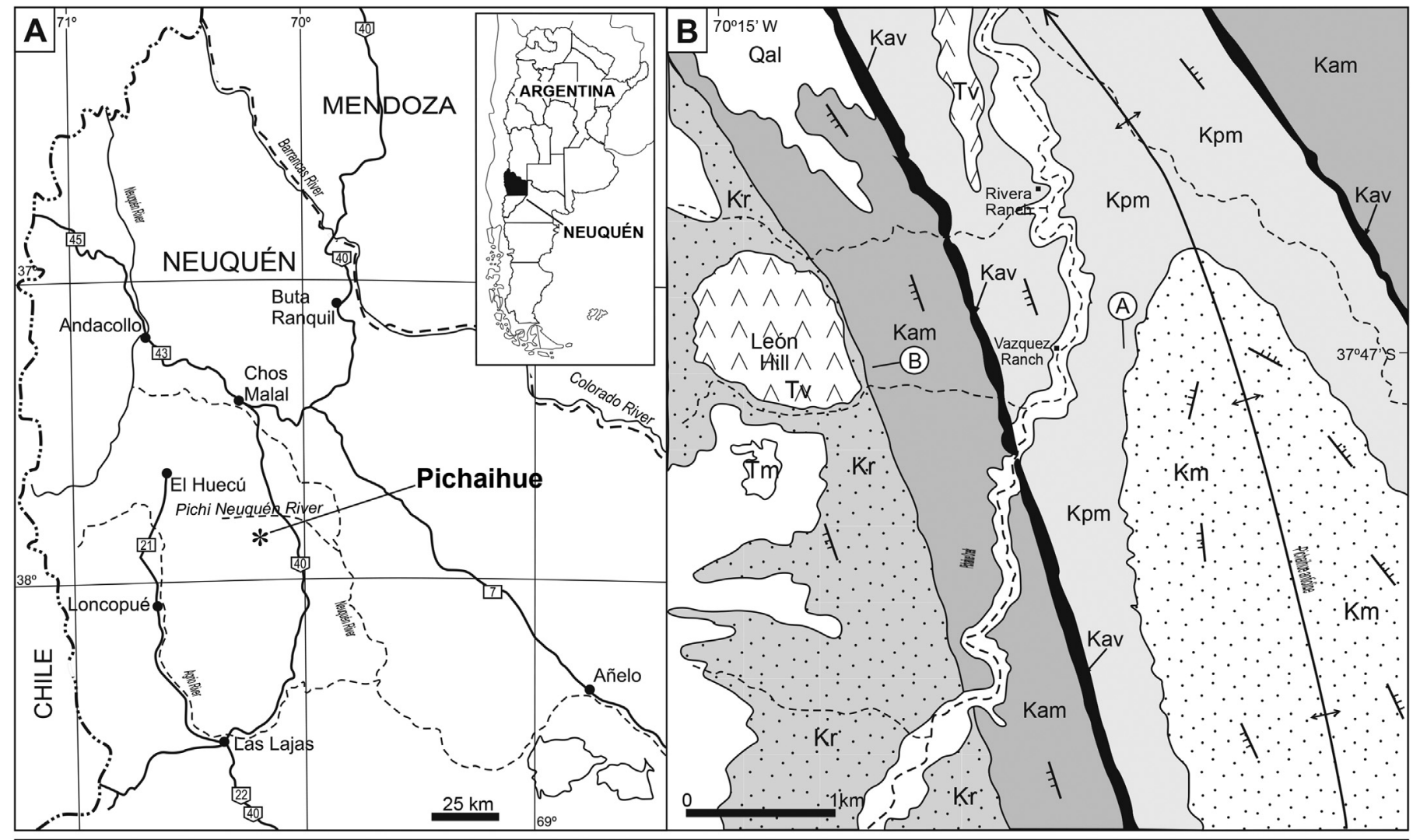

\begin{tabular}{|c|c|c|c|c|}
\hline \multicolumn{5}{|c|}{ REFERENCES } \\
\hline Qal & Quaternary alluvial deposits & Kam & $\begin{array}{l}\text { Agua de la } \\
\text { Mula Member }\end{array}$ & Bedding \\
\hline$T_{N}$ & Cenozoic Cerro León volcanics & Kav & $\begin{array}{l}\text { Lower Cretaceous } \\
\text { Aario Formation }\end{array}$ & Anticline \\
\hline $\mathrm{Tm}$ & $\begin{array}{l}\text { K/P Pichaihue Limestones } \\
\text { (Malargüe Group) }\end{array}$ & $\mathrm{Kpm}$ & Pilmatué Member] & Fin spine locality \\
\hline$\dot{\mathrm{K} r}$. & $\begin{array}{l}\text { Lower Cretaceous } \\
\text { Bajada del Agrio Group }\end{array}$ & $\mathrm{Km}$ & $\begin{array}{l}\text { Lower Cretaceous } \\
\text { Mulichinco Formation }\end{array}$ & (B) Shark tooth locality \\
\hline
\end{tabular}

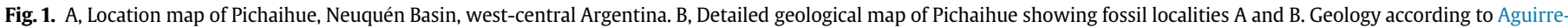
Urreta et al. (2011). 


\subsection{Biostratigraphy and ages}

The fin spine bearing-bed belongs to the upper Valanginian while the shark tooth bearing-bed is younger and belongs to the upper Hauterivian (see Fig. 2). Ages are based on associated ammonoids and follow the refined ammonoid zonation of the Agrio Formation proposed by Aguirre-Urreta et al. (2007, 2008a, 2015), and Aguirre-Urreta and Rawson (2012) that in turn has been correlated with the European Standard Zonation (see AguirreUrreta et al., 2007 and Reboulet et al., 2014).

\section{Geological setting}

\subsection{The Neuquén Basin and Agrio Formation}

The Neuquén Basin was a back-arc depocentre developed during Early Jurassic-Early Cretaceous times, located in west-central Argentina along the foothills of the Andes, between $32^{\circ}$ and $40^{\circ}$ South Latitude. Alternating marine and continental deposits accumulated in the basin due to periodic transgressions from the Pacific Ocean. A broadly triangular epeiric sea embayment was formed during times of high sea level (Howell et al., 2005). In particular, the Mendoza Group was deposited from Kimmeridgian to Barremian times and encompasses, from base to top, the Tordillo, Vaca Muerta, Mulichinco, and Agrio formations (Leanza et al., 2006).

The Agrio Formation was defined by Weaver (1931) in the Río Agrio section within the Neuquén Embayment. In the type area, the section reaches more than $1000 \mathrm{~m}$ in which the three members of the unit are well-developed (Fig. 2). The lower or Pilmatué Member is mainly composed of massive clay shales interbedded with thin layers of sandstones and shell beds, and has been interpreted as a shallow marine ramp (shoreface to offshore) with storm influence. The middle or Avilé Member, a thin continental unit, is represented by yellowish-brown cross-bedded coarse sandstones of aeolian and fluvial origin, representing a second-order sea-level fall. The Avilé facies are the result of a short regressive episode at the end of the early Hauterivian (the Intra-Hauterivian Unconformity; Legarreta and Gulisano, 1989), and are covered by a transgressive surface that depicts the return to open marine conditions (Veiga et al., 2002). The upper or Agua de la Mula Member is composed largely of massive shales in the lower part and gray calcareous shales interbedded with sandy limestones and sandstones in the upper part. It represents a new marine transgression into the basin (see Leanza et al., 2006; Spalletti et al., 2011).

Undoubtedly, the Agrio Formation corresponds to one of the most complete Lower Jurassic-Lower Cretaceous marine faunal

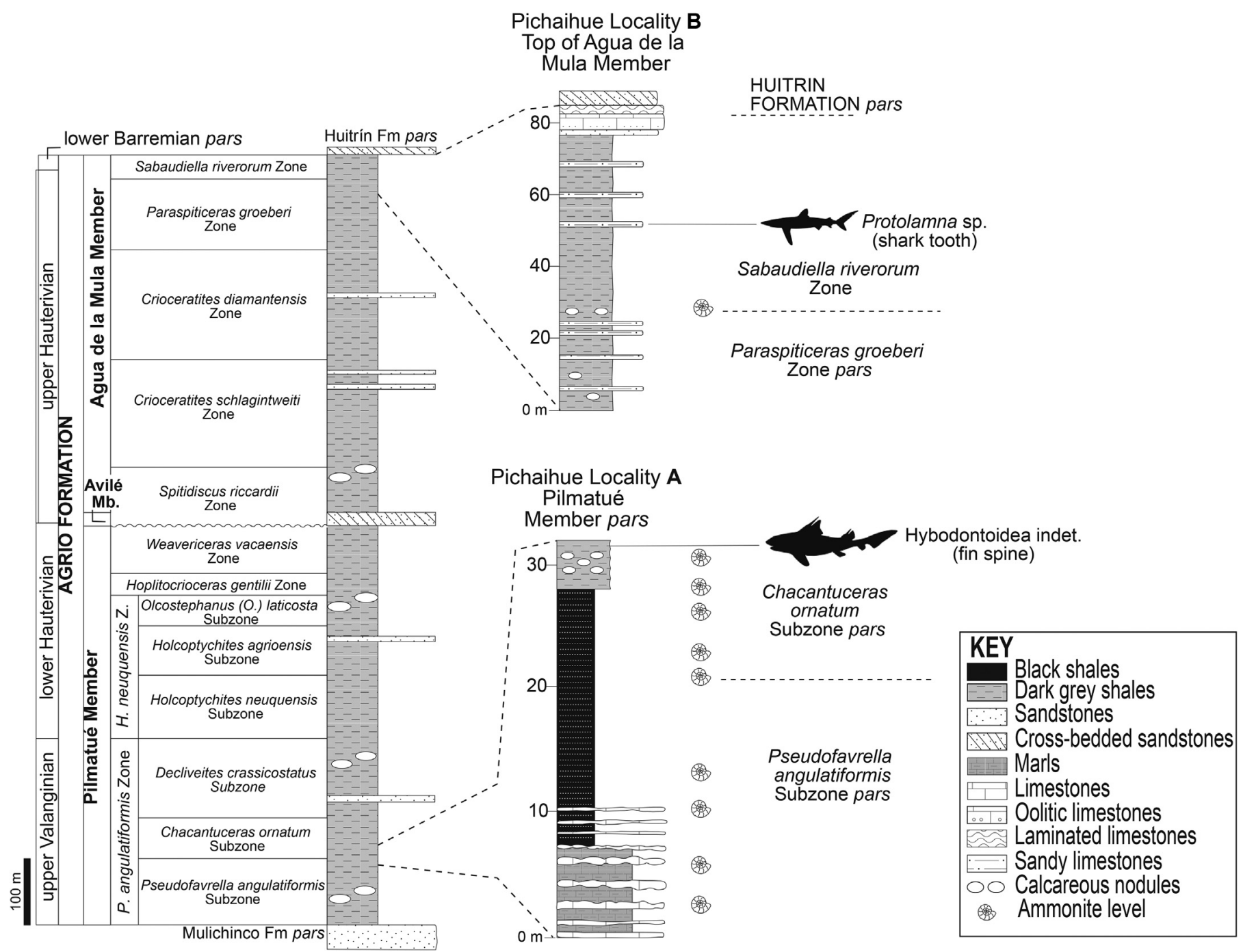

Fig. 2. Stratigraphic log of the Agrio Formation at Pichaihue locality and detailed logs of fossil localities A and B. 
successions of the Southern Hemisphere. The rich and abundant fossil record, first described in detail by Weaver (1931), is composed mainly of invertebrates (bivalves, gastropods, nautiloids, ammonites, corals, crustaceans, echinoderms, bryozoans, and serpulids), diverse trace-fossil assemblages, and scarce vertebrate remains including, up to date, ichthyosaurs (Cichowolski and Lazo, 2000), elasmosaurid plesiosaurs (Lazo and Cichowolski, 2003; O'Gorman et al., 2015), and pycnodontiform fishes (Bocchino, 1977; Cione and Pereira, 1990; Lazo et al., 2005). The fauna as a whole has mainly Tethyan affinities, but some taxa have Andean affinities and even endemic taxa are present (Aguirre-Urreta et al., 2008b). The invertebrates indicate shallow warm-temperate waters (Lazo et al., 2005).

The unit was assigned a late early Valanginian to earliest Barremian age based on integrated biostratigraphy calibrated with $\mathrm{U}-\mathrm{Pb}$ zircon ages (see Aguirre-Urreta et al., 2008a, 2015). Integrated studies on ammonoids, nannoplankton and palynomorphs from the Agrio Formation have provided an excellent biostratigraphic framework for the unit and allows good correlation with the European Standard Zonation (see Reboulet et al., 2014) and the Chilean Chañarcillo Basin zonation (see Aguirre-Urreta et al., 2007; Lazo et al., 2009; Aguirre-Urreta and Rawson, 2012).

\subsection{Fossil localities and ages}

The fin spine and tooth reported here were collected in the Pichaihue section $\left(37^{\circ} 46^{\prime} 59^{\prime \prime} \mathrm{S}, 70^{\circ} 13^{\prime} 03^{\prime \prime} \mathrm{W}\right)$ in two different stratigraphic levels of the Agrio Formation (see localities A and B in Figs. 1B, 2). The Pichaihue section is located along the Pichaihue Creek valley, west of the Chorriaca anticline. Access to the section is through a track running due east off state road 4,12 km east of Colipilli settlement (Fig. 1A). The Agrio Formation is well-exposed on both banks of the stream (Fig. 1B). This section is located towards the western of the Neuquén Basin and thus more distally placed on the marine ramp of the Agrio Formation closer to the open waters of the Pacific Ocean. The unit at Pichaihue shows a clear predominance of fine-grained facies, including thick beds of black and dark gray shales, representing a predominance of lowenergy fall-out deposits. In fact, the fin spine and shark tooth were recovered from dark gray shales and gray sandy limestones, respectively, that represent an offshore low-energy setting below the storm wave base.

The fin spine was collected from locality A, in the lower third of the Pilmatué Member. A 35 m-thick section was measured bed-bybed just in front of the Vázquez Ranch, encompassing the top of the Pseudofavrella angulatiformis Subzone and the base of the Chacantuceras ornatum Subzone, including the fin spine-bearing bed (Fig. 2).

The shark tooth was collected at locality B from beds of the upper third of the Agua de la Mula Member, about $30 \mathrm{~m}$ below the top of the unit. An 80 m-thick section was measured bed-by-bed encompassing the top of the Paraspiticeras groeberi Zone and the Sabaudiella riverorum Zone including the shark tooth-bearing bed near to the eastern flank of León Hill (Fig. 2).

\section{Systematic paleontology}

Subclass Elasmobranchii Bonaparte, 1838 Order Hybodontiformes Maisey, 1975

Superfamily Hybodontoidea Owen, 1846 sensu Zangerl, 1981 Hybodontoidea fam., gen., and sp. indet.

Fig. 3

Material. MOZ-Pv 6988, incomplete dorsal fin spine. Description. Although only two medial portions of the spine are preserved, the general shape indicates that it was elongated. The fin spine was laterally compressed and oval in cross-section. It widens posteriorly and towards the basal opening, of which only a small portion is preserved. The spine had a keel along the anterior margin formed by an enamel ridge. In cross-section, its walls appear festooned (Fig. 3D, F). The surface of the spine is ornamented with strong and apico-basally directed parallel enameloid ridges (= costated sensu Maisey, 1978) that cover the entire free (= exposed) anterior and lateral faces. They are not interrupted and there are not tubercles. Ridges are parallel and equidistant (ca. $1 \mathrm{~mm}$ ). While the anteriormost ridges are compressed, high, and sharp, the posterior most ones are wider and blunt. The fin spine has 27 ridges in the proximal piece and 21 ridges in the distal piece (Fig. 3A). Only fifteen teardropshaped denticle bases are preserved, they are arranged in two rows over the posterior fin spine face (Fig. 3B-C). The denticle disposition may vary over the fin spine length being opposite and/or interspersed. Denticles are approximately $4 \mathrm{~mm}$ long and $3 \mathrm{~mm}$ wide. The distance between each denticle row and the first wall ridge ranges from $5 \mathrm{~mm}$ (distal) to $3.5 \mathrm{~mm}$ (proximal). The internal structure comprises a well-developed central pulp cavity which is oval and narrow. It is surrounded by a layer of lamellar tissue (of about 1-2 mm thick) which forms almost half the thickness of the fin spine wall, a well-developed trabecular tissue (=osteodentine) layer that covers the lamellar one, and a thin enameloid layer (Fig. 3F). Trabecular tissue develops over the entire fin spine, being more developed in its anterior and posterior region (reaching $5 \mathrm{~mm}$ thick) and less developed laterally (reaching $1 \mathrm{~mm}$ wide). The lamellar tissue decreases basally and is absent in the proximal portion. The pulp cavity opens posteriorly in the most basal part of the preserved fin spine (ca. $10 \mathrm{~mm}$ posterior to the last denticles). The total fin spine length may had been c. $300 \mathrm{~mm}$. Based on the reconstruction and proportions of the first fin spine of Hybodus sp. by Maisey (1982), the shark could have measured about $2000 \mathrm{~mm}$ in total length.

Comparisons and discussion. Several chondrichthyans have fin spines preceding their dorsal fins. MOZ-Pv 6988 resembles those of hybodontiforms and differs from the other - xenacanthids, ctenacanthids, squaliforms, heterodontids, holocephalians, and batomorphs - because it has an oval cross-section, the trabecular tissue is more developed anteriorly and posteriorly (being thinner laterally), ridges are parallel and equidistant covering the entire fin spine surface, and because the denticles are arranged in two rows always on the middle part of the posterior face of the spine (not along its borders). Hybodontiform fin spines are difficult or impossible to assign to a certain genus or species (Maisey, 1978; Rees, 1998). Fin spines are known only in Distobatidae (Tribodus Brito and Ferreira, 1989), Hybodontidae (Hybodus Agassiz, 1837, Pryohybodus Erasmo, 1960), Acrodontidae (Acrodus Agassiz, 1838, Asteracanthus Agassiz, 1837), Polyacrodontidae (Palaeobates Meyer, 1849, Polyacrodus Jaekel, 1889), and Lonchidiidae (Lissodus Brought, 1935, Lonchidion Estes, 1964) (Maisey, 1978; Brito in Maisey, 1991; Duffin, 2001; Cappetta, 2012). MOZ-Pv 6988 differs from Asteracanthus and some Late Cretaceous Hybodus, because in those genera the ridges of the fin spines are replaced by tubercles arranged in longitudinal series (Cappetta, 2012). Spines of Lonchidiidae (Lissodus, Lonchidion) present only one series of posterior denticles (Cappetta, 2012). MOZ-Pv 6988 appears difficult to distinguish from fin spines of the distobatid Tribodus, hybodontids, the acrodontid Acrodus, and polyacrodontids. However, Tribodus spines are smaller (up to $125 \mathrm{~mm}$ in length). The material studied here shows some differences but also similarities to members of Hybodontidae: for instance, MOZ-Pv 6988 has a double series of denticles, a character shared with Hybodus. 

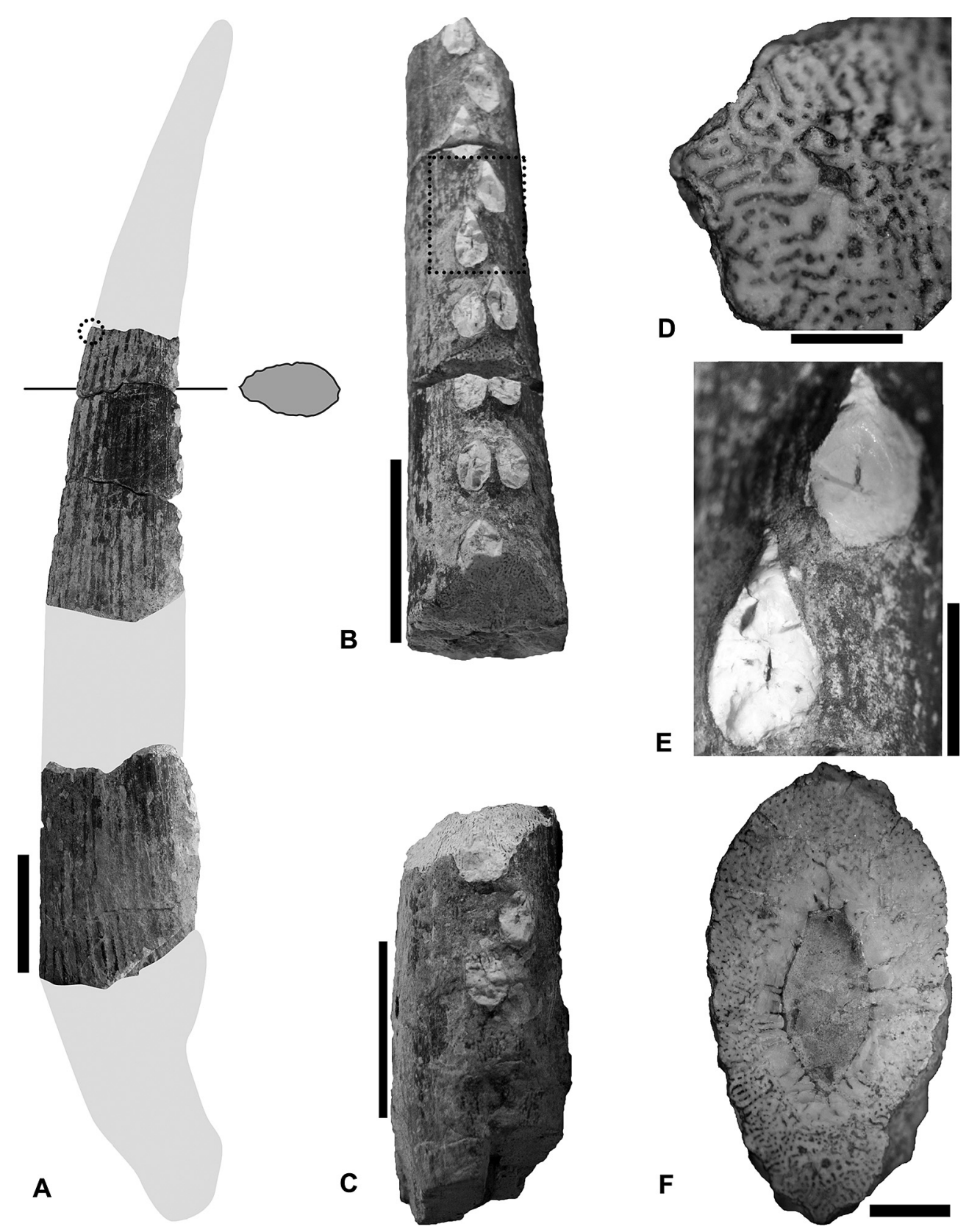

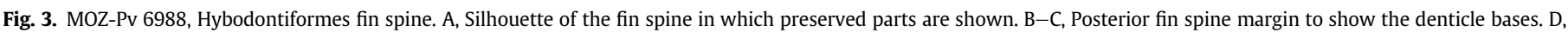

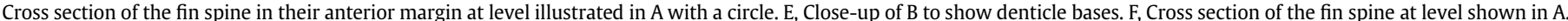
Scale bars $=20 \mathrm{~mm}$ in $\mathrm{A}-\mathrm{C} ; 2 \mathrm{~mm}$ in $\mathrm{D} ; 3 \mathrm{~mm}$ in $\mathrm{E}-\mathrm{F}$.

Order Lamniformes Berg, 1958

Family Eoptolamnidae Kriwet, Klug, Canudo, and Cuenca-Bescós, 2008

Genus Protolamna Cappetta, 1980a

\section{Protolamna sp.}

Fig. 4

Material. MOZ-Pv 6989, an incomplete tooth.

Description. MOZ-Pv 6989 is a small tooth (4 mm high). The tip of the cusp is missing. The cusp is narrow, slightly convex labially and strongly cambered lingually. It is not lingually bent and the labial face base is depressed. The mesial and distal edges of the main cusp change their direction abruptly. A complete, large, well separated, and lingually pointing distal lateral cusplet is preserved; its lingual face is strongly convex and the labial face is flat. The cutting edges are complete. The mesial lateral cusplet is missing. There are very strong lingual, mainly parallel folds in the whole preserved portion of the main cusp and lateral cusplet and strong basal labial parallel folds in the main cusp and lateral cusplet (possibly $1 / 5$ of the crown height). The base of the labial crown is convex, not triangular. The labial crown-root boundary is concave, forming a turned " $U$." The root branches are long and dissimilar, with expanded bases. The lingual protuberance is not preserved.

Comparison and discussion. The material is morphologically similar to teeth of the Cretaceous carcharhiniforms genus Pteroscyllium Cappetta, 1980b and lamniform family Eoptolamnidae (see Kriwet et al., 2008; Cappetta, 2012). However, after a radiograph the 
specimen MOZ-Pv 6989, does not shown a pulp cavity (A. Cione pers. obs. 2017). Moreover, MOZ-Pv 6989 differs from Pteroscyllium in that the lateral cusplet does not show increased lingual orientation relative to the main cusp, the labial ornamentation is less strong, and the main cusp and lateral cusplet have very large basoapical ridges on the lingual face (Kriwet et al., 2009; Schmitz et al., 2010). Besides, the present material is much older than the oldest record of that genus (Aptian; Cappetta, 2012). MOZ-Pv 6989 differs from the eoptolamnid Eoptolamna Kriwet et al., 2008 in the general shape, the absence of a distinct median crest extending from the base to almost the apex of the crown, the lateral cusplets separated from the main cusp and in the same line than main cusp, and the less convex lingual face of main cusp (see Kriwet et al., 2008; Guinot et al., 2013). MOZ-Pv 6989 differs from the eoptolamnid Leptostyrax Willinston, 1900 in the wider, basally unconstricted cusp, lateral cusplets not needle-like and separated from main cusp, cutting edges continuous between main cusp and lateral cusplets, and root lobes uncompressed not forming a V-shaped labial crown/root boundary (see Kriwet et al., 2009; Schmitz et al., 2010). MOZ-Pv 6989 resembles teeth of the eoptolamnid genus Protolamna in the following traits: slender lateral cusplets widely separated from main cusp; lateral cusplets in plane of labial side of main cusp; labial crown-root boundary distinctly concave, forming a turned "U" in anterior and lateral teeth; bulky and high root (see Rees, 2005; Schmitz et al., 2010; Guinot et al., 2013). MOZ-Pv 6989 is similar, in labial view, to the paratype 1 of Protolamna sarstedtensis Schmitz et al., 2010 (figs. 3.9-10) from the early Barremian of NW Germany. However, it differs in the strong lingual ornamentation and distally expanded root branches. The genus Protolamna was named for teeth from the Aptian of France by Cappetta (1980a). The genus was recognized from the Valanginian to the Maastrichtian (Cappetta, 2012; Guinot et al., 2013). Seven species have been assigned to the genus so far (Kriwet et al., 2008, 2009; Cappetta, 2012). However, the morphological diversity that the teeth assigned to Protolamna show suggests that they could represent more than one genus (Kriwet, 1999). This is the first record of Protolamna in South America.

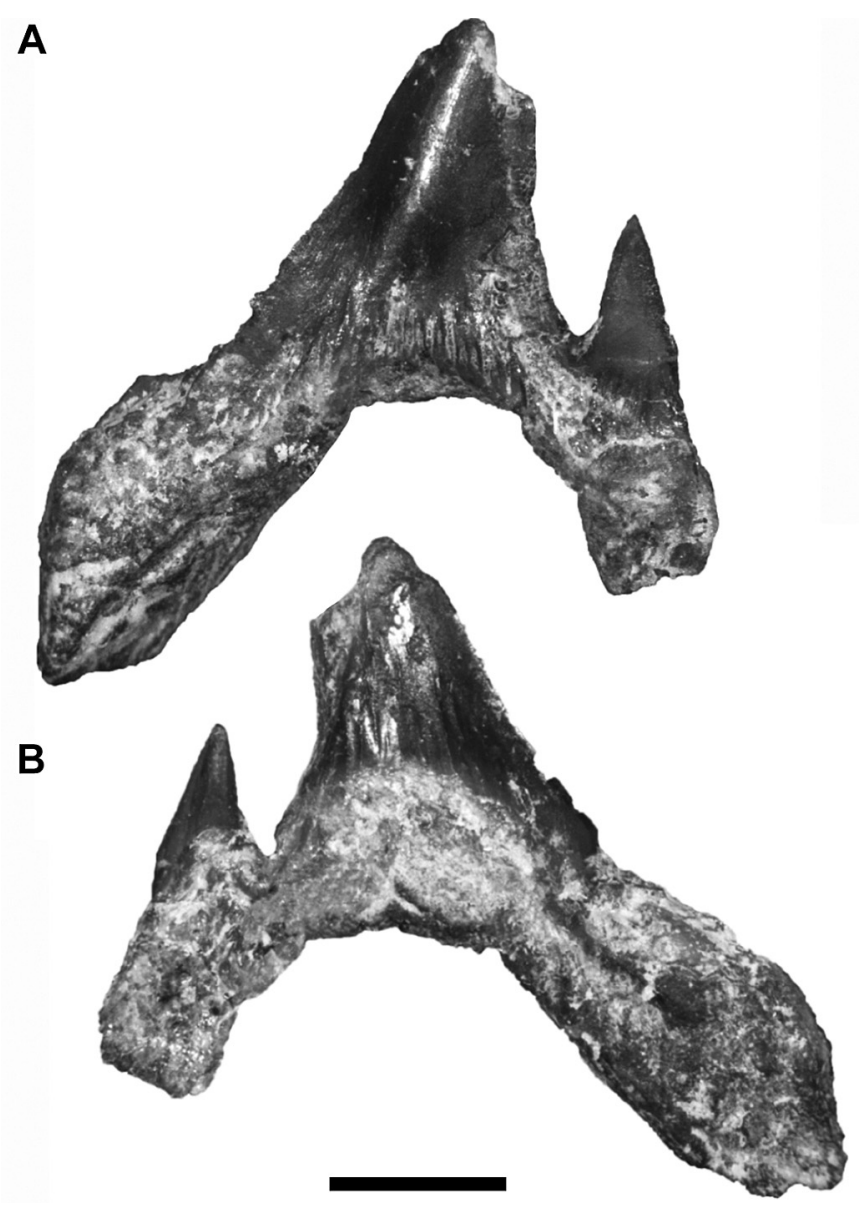

Fig. 4. MOZ-Pv 6989, Protolamna sp. A, Labial view. B, Lingual view. Scale bar $=2 \mathrm{~mm}$.

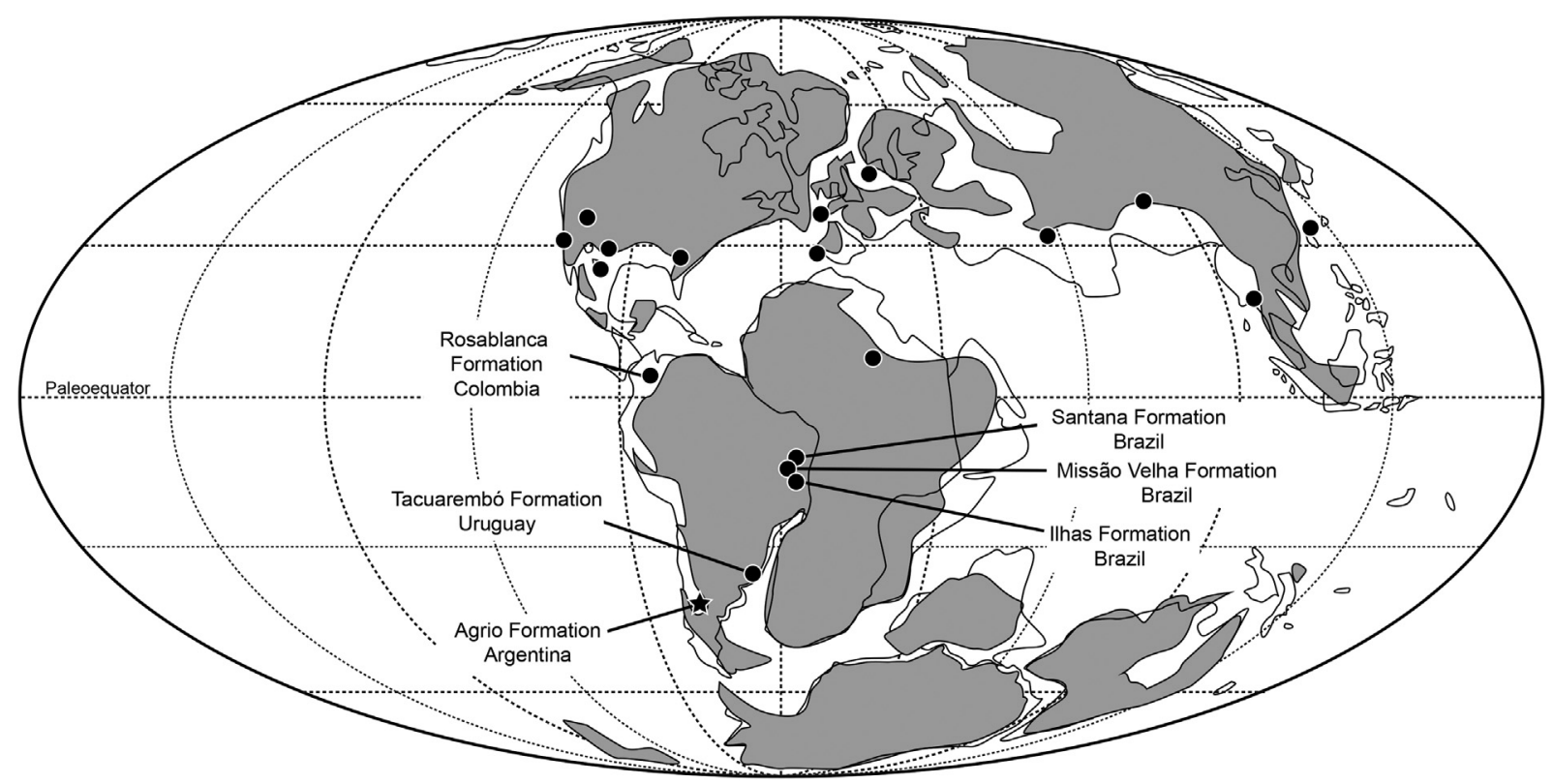

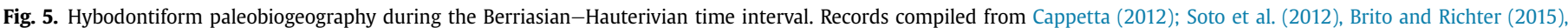

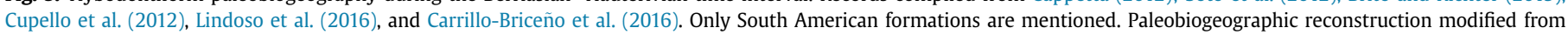
Lazo (2007) and Smith et al. (1994). 


\section{Final remarks}

Chondrichthyans are very poorly known from Jurassic and Lower Cretaceous times of southwestern Gondwana (Fig. 5). Actually, the fin spine and tooth described here are the first chondrichthyans of the Valanginian-Hauterivian time interval. The fin spine, along with the Late Jurassic spine from the Vaca Muerta Formation (Cione et al., 2002), represent the southernmost hybodontiform marine records in the world. Despite hybodontiforms have a worldwide distribution being commonly found and highly diverse during the Mesozoic in Europe, North America, Asia, and Africa, they are scarce in South America. A bias due to collection may not be discarded. Neoselachians are relatively well known in Jurassic rocks. One of the most important crown groups, Lamniformes, is known since the Valanginian. Both hybodontids and Protolamna became extinct during the $\mathrm{K}-\mathrm{Pg}$ mass extinction. Pre-Aptian Cretaceous elasmobranch faunas are at the crossroads between Jurassic faunas (acrodontids, stem hexanchiforms, synechodontiforms, small-sized orectolobiforms, and carcharhiniforms) and mid-Cretaceous faunas characterized by diverse lamniforms (cretoxyrhinids, archaeolamnids, anacoracids, and paraisurids), numerous ptychodontids and batoids (sclerorhynchiforms, rajids, and cyclobatids), and some squaliforms (squalids and centrophorids) (Guinot and Cavin, 2015). According to Guinot and Cavin (2015), Lamniformes probably appeared in the Middle Jurassic although they remained relatively inconspicuous (mainly Eoptolamna and Protolamna) until the Aptian-Albian. Therefore, any information about Lamniformes from pre-Aptian times is relevant.

\section{Acknowledgments}

The authors would like to thank A. Garrido and B. Boilini (MOZ), and M. Reguero (MLP) who provided access to study material under their care. This study was funded in part by Agencia Nacional de Promoción Científica y Técnica (PICT 07-12359, PICT 2014-2357, PICT 2015-0253), Banco Interamericano de Desarrollo (BID 1201/ OC-AR), and Universidad Nacional de La Plata (UNLP N676) to ALC and SGC and PICT 2014-0016 to MBAU. The editor E. Koutsoukos and the reviewers J. Kriwet, L. Cavin and an anonymous reviewer are thanked for the valuable information and comments which improved the manuscript. This is the contribution R-205 of the Instituto de Estudios Andinos (IDEAN).

\section{References}

Agassiz, L., 1837. Recherches sur les poissons fossiles part III. Petitpierre, Neuchâtel et Soleure 41-53.

Agassiz, L., 1838. Recherches sur les poissons fossiles part III. Petitpierre, Neuchâtel et Soleure 139-149.

Aguirre-Urreta, M.B., Rawson, P.F., 2012. Lower Cretaceous ammonites from the Neuquén Basin, Argentina: a new heteromorph fauna from the uppermost Agrio Formation. Cretaceous Research 35, 208-216.

Aguirre-Urreta, M.B., Mourgues, A.F., Rawson, P.F., Bulot, L.G., Jaillard, E., 2007. The Lower Cretaceous Chañarcillo and Neuquén Andean basins: ammonoid biostratigraphy and correlations. Geological Journal 42, 143-173.

Aguirre-Urreta, M.B., Pazos, P.J., Lazo, D.G., Fanning, C.M., Litvak, V.D., 2008a. First U-Pb SHRIMP age of the Hauterivian stage, Neuquén Basin, Argentina. Journal of South American Earth Sciences 26, 91-99.

Aguirre-Urreta, M.B., Casadío, S., Cichowolski, M., Lazo, D.G., Rodríguez, D.L., 2008b. Afinidades paleobiogeográficas de los invertebrados cretácicos de la Cuenca Neuquina, Argentina. Ameghiniana 45, 591-612.

Aguirre-Urreta, M.B., Tunik, M., Naipauer, M., Pazos, P.J., Ottone, E., Fanning Ramos, V.A., 2011. Malargüe Group (Maastrichtian-Danian) deposits in the Neuquén Andes, Argentina: implications for the onset of the first Atlantic transgression related to Western Gondwana break-up. Gondwana Research 19 $482-494$.

Aguirre-Urreta, M.B., Lescano, M., Schmitz, M., Tunik, M.A., Concheyro, A.G. Rawson, P.F., Ramos, V.A., 2015. Filling the gap: new precise Early Cretaceous radioisotopic ages from the Andes. Geological Magazine 152, 557-564.

Arratia, G., Cione, A.L., 1996. The record of fossil fishes of Southern South America. Müncher Geowissenschaftliche Abhandlugen 30 A, 9-72.
Bell, M.C., Suárez, M., 1997. The Lower Cretaceous Apeleg Formation of the Aisén basin, southern Chile. Tidalsandbar deposits of an epicontinental sea. Revista Geológica de Chile 24, 203-226.

Berg, L.S., 1958. System der rezenten und fossilen Fischartigen und Fische. Deutescher Verlag der Wissenchaften, Berlin, p. 310.

Bocchino, A., 1977. Un nuevo Gyrodontidae (Pisces, Holostei, Pycnodontiformes) de la Formación Agrio (Cretácico Inferior) de la Provincia de Neuquén, Argentina. Ameghiniana 14, 175-185.

Bonaparte, C.L., 1838. Selachorum tabula analytica. Nuovi Annali Scienze Naturali 2 , 195-214.

Brito, P., Ferreira, P.L.N., 1989. The first hybodont shark, Tribodus limae n. gen., n. sp., from the Lower Cretaceous of Chapada do Araripe (north-east Brazil). Anais Academia Brasileira de Ciencias 61, 53-57.

Brito, P., Richter, M., 2015. The contribution of Sir Arthur Smith Woodward to the palaeoichthyology of Brazil-Smith Woodward's types from Brazil. Geological Society of London Special Publications 430. http://dx.doi.org/10.1144/ SP430.12.

Brito, P., Leal, M.E., Richter, M., 2013. A new lower Cretaceous guitarfish (Chondrichthyes, Batoidea) from the Santana Formation, northeastern Brazil. Boletim do Museo Nacional, Geologia 76, 1-13.

Brought, J., 1935. On the structure and relationships of the hybodont sharks. Memoirs and Procceeding Manchester Literature and Phylosophy Society 79, $35-49$.

Cappetta, H., 1980a. Les Sélaciens du Crétacé supérieur du Liban. I. Requins. Palaeontographica, Abteilung A 168, 69-148.

Cappetta, H., 1980b. Modification du statut générique de quelques espèces de sélaciens crétacés et tertiaries. Paleovertebrata 10, 29-42.

Cappetta, H., 2012. Chondrichthyes-Mesozoic and Cenozoic Elasmobranchii: Teeth. In: Schultze, H.-P. (Ed.), Handbook of Paleoichthyology: 3E. Verlag Dr. Friedrich Pfeil, München, p. 512.

Carrillo-Briceño, J.D., Cadena, E.A., Dececchi, A.T., Larson, H.C.E., Du, T.Y., 2016. First record of a hybodont shark (Chondrichthyes: Hybodontiformes) from the Lower Cretaceous of Colombia. Neotropical Biodiversity 2, 81-86.

Cichowolski, M. Lazo, D.G. 2000, Lower Cretaceous Marine Reptiles from Argentina. Abstracts 31 International Geological Congress, CD-rom. Rio de Janeiro, Brazil.

Cione, A.L., 1999. First report of a Jurassic ray outside of Europe. In: Arratia, G., Schultze, H.-P. (Eds.), Mesozoic Fishes 2 Systematics and Fossil Record. Verlag Dr. Friedrich Pfeil, Munich, pp. 21-28.

Cione, A.L., Medina, F., 2009. The oldest hexanchiform shark from Southern Hemisphere (Neoselachii; early Cretaceous, Antarctica). Antarctic Science 21, $501-504$.

Cione, A.L., Pereira, S.M., 1990. Los peces del Jurasico posterior a los movimientos intermalmicos y del Cretacico inferior de Argentina. In: Volkheimer, W., Musacchio, E.A. (Eds.), Bioestratigrafía de los Sistemas Regionales del Jurásico y Cretácico en América del Sur. Vol. 1: Jurásico anterior a los movimientos intermálmicosEditorial Inca, Mendoza, pp. 385-395.

Cione, A.L., Acosta Hospitaleche, C., Mennucci, J.A., Cocca, S., 2002. The first shark from the Triassic-Jurassic of South America. Neues Jahrbuch für Geologie und Paläontologie 1, 9-18.

Cupello, C.D., Bermúdez-Rochas, D.D., Martill, D.M., Brito, P.M., 2012. The Hybodontiformes (Chondrichthyes: Elasmobranchii) from the Missão Velha Formation (?Lower Cretaceous) of the Araripe Basin, North-East Brazil. Comptes Rendus Palevol 11, 41-47.

Duffin, C.J., 2001. Synopsis of the selachian genus Lissodus Brough, 1935. Neues Jahrbuch für Geologie und Paläontologie Abhandlungen 221, 145-218.

Erasmo, G.d'., 1960. Nuouvi avanzi ittiolitici della "Serie di Lugh" in Somalia conservato in il Museo Geologico di Firenze. Palaeontolographica Italica 55, $1-23$.

Estes, R., 1964. Fossil vertebrates from the Late Cretaceous Lance Formation, eastern Wyoming. University of California Publications in Geological Sciences 49, $1-180$.

Guinot, F., Cavin, L., 2015. 'Fish' (Actinopterygii and Elasmobranchii) diversification patterns through deep time. Biological Review. http://dx.doi.org/10.1111/ brv.12203.

Guinot, F., Underwood, C., Cappetta, H., Ward, D.J., 2013. Sharks (Elasmobranchii: Euselachii) from the Late Cretaceous of France and the UK. Journal of Systematic Palaeontology 11, 589-671.

Howell, J.A. Schwarz, E., Spalletti, L.A., Veiga, G.D., 2005. The Neuquén Basin: an overview. In: Veiga, G.D., Spalletti, L.A., Howell, J.A., Schwarz, E. (Eds.), The Neuquén Basin, Argentina: A Case Study in Sequence Stratigraphy and Basin Dynamics. Geological Society of London, Special Publication 252, pp. 1-14.

Jaekel, E., 1889. Die Selachier aus dem oberern Muschelkalk Lothringens. Abhandlungen zur geologischen Specialkarte von Elsass-Lothringen 3, 273-332.

Kriwet, J., 1999. Neoselachier (Pisces, Elasmobranchii) aus der Unterkreide (unteres Barremium) von Galve und Alcaine (Spanien, ProvinzTeruel). PalaeoIchthyologica 9, 113-142.

Kriwet, J., 2003. First record of an Early Cretaceous shark (Chondrichthyes, Neoselachii) from Antarctica. Antarctic Science 15, 507-511.

Kriwet, J., Klug, S., Canudo, J.I., Cuenca-Bescós, G., 2008. A new Early Cretaceous lamniform shark (Chondrichthyes, Neoselachii). Zoological Journal of the Linnean Society 154, 278-290.

Kriwet, J., Nunn, E.V., Klug, S., 2009. Neoselachians (Chondrichthyes, Elasmobranchii) from the Lower and lower Upper Cretaceous of north-eastern Spain. Zoological Journal of the Linnean Society 155, 316-347. 
Lazo, D.G., 2007. The bivalve Pholadomyagigantea in the Early Cretaceous of Argentina: taxonomy, taphonomy, and paleogeographic implications. Acta Paleontologica Polonica 52, 375-390.

Lazo, D.G., Cichowolski, M., 2003. First Plesiosaur remains from the Lower Cretaceous of the Neuquén Basin, Argentina. Journal of Paleontology 77, 784-789.

Lazo, D.G., Cichowolski, M., Rodriguez, D.L., Aguirre-Urreta, M.B., 2005. Lithofacies, palaeoecology and palaeoenvironments of the Agrio Formation, Lower Cretaceous of the Neuquén Basin, Argentina. In: Veiga, G.D., Spalletti, L.A., Howell, J.A., Schwarz, E. (Eds.), The Neuquén Basin, Argentina: A Case Study in Sequence Stratigraphy and Basin Dynamics. Geological Society of London Special Publications 252, pp. 295-315.

Lazo, D.G., Concheyro, A.G., Ottone, G.E., Guler, V., Aguirre-Urreta, M.B., 2009. Bioestratigrafía integrada de la Formación Agrio en su localidad tipo, Cretácico Temprano de Cuenca Neuquina. Revista de la Asociación Geológica Argentina 65, 322-341.

Leanza, H.A., Repol, D., Hugo, C.A., Sruoga, P., 2006. Hoja Geológica 3769-31, Chorriaca, provincia del Neuquén. Programa Nacional de Cartas Geológicas de la Republica Argentina a escala 1:100.000, Boletin 354. SEGEMAR, Buenos Aires, p. 93.

Legarreta, L. Gulisano, C.A., 1989. Análisis estratigráfico secuencial de la Cuenca Neuquina (Triásico Superior-Terciario Inferior, Argentina). In: Chebli, G.A., Spalletti, L.A. (Eds.), Cuencas Sedimentarias Argentinas. Simposio de Cuencas Sedimentarias Argentinas. X Congreso Geológico Argentino, Tucumán, pp. 221-243.

Lindoso, R.M., Maisey, J.G., de Souza Carvalho, I., 2016. Ichthyofauna from the Codó Formation, Lower Cretaceous (Aptian, Parnaíba Basin), Northeastern Brazil and their paleobiogeographical and paleoecological significance. Palaeogeography, Palaeoclimatology, Palaeoecology 447, 53-64.

Maisey, J.G., 1975. The interrelationships of phalacanthous selachians. Neues Jahrbuch für Geologie und Paläontologie 1975, 553-557.

Maisey, J.G., 1978. Growth and form of finspines in hybodont sharks. Palaeontology 22, 657-666.

Maisey, J.G., 1982. The anatomy and interrelationships of Mesozoic hybodont sharks. American Museum Novitates 2724, 1-48.

Maisey, J.G., 1991. Santana fossils: and illustrated atlas. TFH Publishers, Neptune City, p. 459.

Meyer, H. von, 1849. Fische, Crustaceen, Echinodermen und andere Versteinerungen aus dem Muschelkalk Oberschlesiens. Palaeontographica 1, 216-242.

O'Gorman, J.P., Lazo, D.G., Luci, L., Cataldo, C.S., Schwarz, E., Lescano, M., AguirreUrreta, M.B., 2015. New plesiosaur records from the Lower Cretaceous of the Neuquén Basin, west-central Argentina, with an updated picture of occurrences and facies relationships. Cretaceous Research 56, 372-387.

Owen, R., 1846. Lectures on the Comparative Anatomy and Physiology of the Vertebrate Animals, Delivered at the Royal College of Surgeons of England in 1844 and 1846, Part 1: Fishes. Longman, Brown, Green and Longmans, London, p. 308.

Patterson, C., 1966. British Walden Sharks. Bulletin of the British Museum Natural History 11, 281-350.
Perea, D., Ubilla, M., Rojas, A., Goso, C., 2001. The West Gondwanan occurrence of the hybodontid shark Priohybodus and the Late Jurassic-Early Cretaceous age of Tacuarembó Formation, Uruguay. Palaeontology 44, 1227-1235.

Pinheiro, F.L., Figueiredo, A.E.Q., Fortier, D.C., Viana, M.S.S., Schultz, C.L., 2011. Fauna de vertebrados Eocretácicos de um afloramento da Bacia de Lima Campos, Ceará, Brasil. Revista Brasileira de Paleontologia 14, 189-198.

Reboulet, S., Szives, O., Aguirre-Urreta, M.B., Barragán, R., Company, M., Idakieva, V. Ivanov, M., Kakabadze, M.V., Moreno-Bedmar, J.A., Sandoval, J., Baraboshkin, E.J., Caglar, M.K., Fozy, I., González-Arreola, C., Kenjo, S., Lukeneder, A. Raisossadat, S.N., Rawson, P.F., Tavera, J.M., 2014. Report on the 5th International Meeting of the IUGS Lower Cretaceous Ammonite Working Group, the "Kilian Group" (Ankara, Turkey, 31st August 2013). Cretaceous Research 50, 126-137.

Rees, J., 1998. Early Jurassic selachians from the Hasle Formation on Bornholm, Denmark. Acta Geologica Polonica 43, 439-452.

Rees, J., 2005. Neoselachian shark and ray teeth from the Valanginian, Lower Cretaceous, of Wawal. Palaeontology 48, 209-221.

Schmitz, L., Thies, D., Kriwet, J., 2010. Two new lamniform sharks (Leptostyrax stychi sp. nov. and Protolamna sarstedtensis sp. nov.) from the Early Cretaceous of NW Germany. Neues Jahrbuch für Geologie und Paläontologie Abhandlungen 257, 283-296.

Smith, A.G., Smith, D.G., Funnell, B.M., 1994. Atlas of Mesozoic and Cenozoic Coastlines. Cambridge University Press, Cambridge, p. 109.

Soto, M., Perea, D., Toriño, P., 2012. New remains of Priohybodus arambourgi (Hybodontiformes: Hybodontidae) from Late Jurassic-? earliest Cretaceous deposits in Uruguay. Cretaceous Research 35, 118-123.

Spalletti, L.A., Veiga, G.D., Schwarz, E., 2011. La Formación Agrio (Cretácico Temprano) en la Cuenca Neuquina. In: Leanza, H., Arregui, C., Carbone, O. Danieli, J.C., Vallés, J.M. (Eds.), Geología y Recursos Naturales de la Provincia del Neuquén. XVII Congreso Geológico Argentino, Relatorio, Jujuy, pp. $145-160$.

Suárez, M.E., 2015. Tiburones, Rayas y Quimeras (Chondrichthyes) fósiles de Chile. Publicación Ocasional del Museo Nacional de Historia Natural de Chile 63, 17-33.

Suárez, M.E., Otero, R.A., 2011. First record of a neoselachian shark in the Jurassic of Chile. Ameghiniana 48, R213.

Veiga, G.D., Spalletti, L.A., Flint, S., 2002. Aeolian/fluvial interactions and highresolution sequence stratigraphy of a non-marine lowstand wedge: the Avile Member of the Agrio Formation (Lower Cretaceous), central Neuquén Basin, Argentina. Sedimentology 49, 1001-1019.

Weaver, C.E., 1931. Paleontology of the Jurassic and Cretaceous of West Central Argentina. Memoirs of the University of Washington 1, 1-595.

Willinston, S.W., 1900. Cretaceous fishes, selachians and pycnodonts. Publications of the University Geological Survey Kansas 6, 237-256.

Woodward, A.S., 1888. Notes on some vertebrate fossils from the Province of Bahia, Brazil, collected by Joseph Mawson. Annals and Magazine of Natural History 2, $132-136$.

Zangerl, R., 1981. Chondrichthyes I: Paleozoic Elasmobranchii. In: Schultze, H.-P. (Ed.), Handbook of Paleoichthyology. Gustav Fischer Verlag, Stuttgart, pp. 1-115. 